\title{
Utilization of Polythene Mulching under Protected Cultivation of Tomato: A Method to Minimize Amount of Irrigation Under Semi Arid Ecosystem of Jharkhand, India
}

\author{
Chanchila Kumari*, Binit Kumar and Manish Kumar \\ ${ }^{1}$ ICAR-NRRI-CRURRS-KVK, Koderma, 825109 (Jharkhand) \\ ${ }^{2}$ ICAR-IISR, Lucknow, 226002 (Uttar Pradesh), India \\ *Corresponding author
}

\begin{tabular}{l} 
Ke y w o r d s \\
$\begin{array}{l}\text { Poly house, } \\
\text { Polythene } \\
\text { mulching, Drip } \\
\text { irrigation, Soil } \\
\text { moisture and } \\
\text { rainfed }\end{array}$ \\
Article Info \\
$\begin{array}{l}\text { Accepted: } \\
\text { 26 July 2018 } \\
\text { Available Online: } \\
\text { 10 August } 2018\end{array}$ \\
\hline
\end{tabular}

A B S T R A C T

The trails have been conducted at semi tropical upland rainfed ecosystem of village Urwa Block: Chandwara, Koderma, Jharkhand during summer season in poly house. The Black polytheen sheet has been utilized for providing mulching in experiment. The different growth parameters like morphological character, dry matter accumulation and number of fruits, weight of fruit per cluster, yield per hectare including cost benefit ratio have been calculated between mulched and unmulched treatment combination. Data revealed that experiment was exhibit the impact of black polytheen sheet with the thickness of 25 micron recorded best result in comparison to unmulched treatment combination for Plant height $(92.2 \mathrm{~cm})$, minimum days took for $50 \%$ flowering (72.5 days), maximum number of primary branches (115.3), number of secondary branches (225.3), dry matter (38.2), fruit weight (84.3g), leaf area index (2.25) and yield (33.2 ton/ha) has been recorded. The yield and yield-contributing characters in the mulched treatments for all levels of irrigation were significantly higher over unmulched treatments. Drip irrigation with black polythene sheet recorded highest net returns $(28,740 \mathrm{Rs} / \mathrm{ha})$ and benefit cost ratio (1:1.23) in tomato. However, it was found that drip irrigation besides black polytheen mulching gave a saving of $38 \%$ water resulted into $42 \%$ higher fruit yield compared to surface irrigation. The study reveals that drip irrigation with mulching has an explicit role in increasing the land and water productivity of tomato.

\section{Introduction}

Tomato (Lycopersicon esculentum Mill.) is one of the rich source of mineral, vitamins, organic acid besides most popular, cash earning, remunerative and versatile vegetable crops in Jharkhand. The pulp and juice is digestible, promoter of gastric secretion and blood purifier (Bhella, 1988). The main constraint of its cultivation round the year in plains including harsh geotropical regions like Koderma where weathers condition during winter and summer season is extremes. The optimum temperature required for its cultivation is $15-27^{\circ} \mathrm{C}$. At high and low temperatures, there is low germination of 
seeds, poor plant growth, flower drop, poor fruit set and ripening. At high temperatures, generally the quality of fruits is poor and there is high incidence of sun-scald (Agong et al., 2001). Under extreme high and low temperature conditions, the yield and quality of fruits is reduced. Mild winter condition in plains is ideal for seed germination, plant growth, fruit set, fruit development and ripening (Singh et al., 2005). For successful crop production about $285 \mathrm{~mm}$ water is required during plant establishment, flowering, fruit setting and fruit development stage (Singh and Kamal, 2012). But irrigation facilities are not available in all the regions of the Jharkhand, specially the drought facing state like Jharkhand where annual average rainfall is $1050 \mathrm{~mm}$ and we did not get ever optimum rainfall just because of climatic changes. The brutal impact of climate change has been observed on decreasing water availability in farm pond, well, canal and other natural source of irrigation. Sometimes, many of the farmers' cannot provide irrigation due to unavailability of irrigation facilities or even can't afford the expenses of irrigation. Novel irrigation technologies need to test under local environment and particularly in agricultural production system (Bhujbal et al., 2015). Under this situation mulching and drip irrigation system could be a good substitute means for irrigation to make soil moist. The mulching facilities provide other cost effect advantages as followed (Choudhary et al., 2012): It is completely impermeable to water. It prevents the evaporation of moisture from the soil and thus limits the water losses and conserves moisture and early germination. Mulching create a warm temperature even during night time which enables seeds to germinate quickly and for young plants to rapidly establish a strong root growth system. Mulching can reduce the loss of plant nutrient through leaching. Polythene mulching plays a major role in soil solarization process. Mulching can also provide a barrier to soil pathogens. Mulching develop a microclimate underside of the sheet, which is higher in carbon di-oxide due to the higher level of microbial activity. Water erosion is completely averted since soil is completely covered from bearing action of rain drops. Polythene mulching is crucial for Jharkhand agriculture system in view of the changing technological scenario for boosting crop yields and productivity under rainfed reason. The tomato fruits are thus available for a short period (mid April to mid June) (Singh et al., 2005). It is a challenge to the vegetable production technology and utilization of natural resources to produce vegetables several times more to meet the needs of the large population. In these circumstances protected cultivation (poly house) production offers great scope (Singh, 2005). There are several factors i.e., suitable varieties, nutrition management, water management, plant protection etc. are responsible for production and productivity of the vegetables (Thakur et al., 1996). Vegetable production in Jharkhand region is significantly depending on the seasonality and weather conditions. Extends of abundance and deficiency in production and availability cause considerable fluctuations in the prices and quality of vegetables. Shrinking a balance between all-season availability of high quality vegetables with minimum environment impact, and still to remain economically competitive in this time of globalization, is a major challenge for the modern technology of crop production (Thakur et al., 2000). Under open field cultivation, providing healthy and favorable micro climatic condition for growing plant is not possible but the protected cultivation of vegetable crops open a broad range to minimize demand of seasonal as well as off season crops in the market (Agrawal et al., 2010). Greenhouses, rain shelters, plastic tunnels, mulches, insect-proof net houses, shade nets, etc. are used as protective structures and means depending on the 
requirements and cost-effectiveness (Mukherjee et al., 2010). Besides modifying microclimate, these protective structures provide protection against wind, rain and insects. Protected cultivation offers several advantages to produce vegetables of high quality and yields-particularly during the offseason when prices are higher, thus using the land and other resources more efficiently (Teasdale and Mohler, 2000). This becomes relevant to vegetable growers in India who have land holding smaller than one hectare. They would be interested in a technology which helps them to produce more crops each ear from their land, particularly during offseason when prices are higher. Other advantages of poly house cultivation include timely harvest as per market demand; higher yield due to better management, optimum use of land and increase in harvesting period and raising quality seedlings and plant propagation (Uniyal and Mishra, 2003). Adoption of poly house technology can improve yield and productivity of tomato crop in off season cultivation.

\section{Materials and Methods}

The experiment was conducted in poly house during summer season (March to August) at village Urwa Block: Chandwara, Koderma district, Jharkhand. The experimental site is located at N24.343831, E85.472779 geographical position. The area represents the drought and erratic rainfall semi tropic upland climatic condition. In this experiment the promising and high yielding hybrid of Tomato Swarna Lalima was grown inside polyhouse of size $10 \mathrm{~m}$ x $10 \mathrm{~m}$ (L x B) during the summer season. The nursery was raised inside the polyhouse. The most common pathogenic symptom of damping off (Phythium sp.) has been observed. The 25-30 days old seedlings were transplanted on one meter broad raised bed covered with black polythene sheet which has a thickness of 25 micron (More et al., 2013). The beds have been covered before ten days of transplanting for sanitization of soil against soil born pathogen besides $2 \%$ formalin was used (Ashrafuzzaman et al., 2011). Fertigation was done weekly and the plants were irrigated daily with drip irrigation system, one dripper was provided for each plant. Plants were watered regularly before 12 noon or late evening. Other cultural practices and standard plant protection measures were also adopted from time to time to ensure healthy crop stand. Weeding was done in unmulched treatment set after 30, 45, 60 and 90 days of transplanting (Abdalgabi et al., 2010). Before inception of trail the status of soil health has been check in the laboratory of Krishi Vigyan Kendra, Koderma (Jharkhand). Randomize five plants from each bed were selected for taking morphological and yield contributing characters of tomato.

\section{Results and Discussion}

The effect of Black polythene mulching with drip irrigation system on growth, yield and quality of tomato under protected cultivation gave significant differences in all the parameters including cost benefit ratio of cultivation. The data on vegetative growth, flowering, fruit yield and fruit quality were recorded and statistical analysis. The results so obtained under treatments were summarized like, Plant height and number of branches per plant decreased with unmulched treatment. The minimum number of days took for $50 \%$ flowering, days to first fruit set and first harvesting was taken by the crop planted with mulching with drip irrigation system. The weed intensity was found nil in mulched combination which may reduce the competition with primary crop. Moreover, unmulched pattern required timely weeding and spray of weedicide which results increase the cost of cultivation as well as impose harsh impact on environment. In the recent climatic 
scenario, practice of climate resilient technique will be vital for human kind. This technology generates more profit and suitable for women as it is less drudgery prone activity. By this method farmers can cultivate high value vegetables particularly during lean period when open field cultivation is difficult.
We can also cultivate foreign vegetables by this method and get these vegetables in our country at lower price. It may be concluded that protected cultivation technology suitable for higher production and improve economic status of the farmers (Table 1-4).

Table.1 Detail of treatment combination

\begin{tabular}{|l|l|}
\hline S.No. & Treatment combination \\
\hline 1. & Black Polythene mulching + Drip Irrigation \\
\hline 2. & Unmulched + Surface Irrigation \\
\hline
\end{tabular}

Table.2 Chemical characteristic of soil under polyhouse

\begin{tabular}{|c|c|c|c|c|}
\hline S.No. & Parameter & Content & Unit & Remarks \\
\hline 1. & $\mathrm{pH}$ & 5.24 & - & Acid \\
\hline 2. & EC & 0.06 & $\mathrm{DS} / \mathrm{M}$ & Neutral \\
\hline 3. & $\begin{array}{l}\text { Organic } \\
\text { Carbon }\end{array}$ & 0.43 & $\%$ & Less \\
\hline 4. & Nitrogen & 382.59 & $\mathrm{Kg} / \mathrm{Ha}$ & Neutral \\
\hline 5. & Phosphorus & 18.4 & $\mathrm{Kg} / \mathrm{Ha}$ & Neutral \\
\hline 6. & Potassium & 140.34 & $\mathrm{Kg} / \mathrm{Ha}$ & Neutral \\
\hline 7. & Sulphur & 31.8 & PPM & Neutral \\
\hline 8. & Zinc & 2.61 & PPM & Neutral \\
\hline 9. & Boron & 1.25 & PPM & Neutral \\
\hline 10. & Iron & 15.6 & PPM & Neutral \\
\hline 11. & Manganese & 31.24 & PPM & Neutral \\
\hline 12. & Copper & 2.43 & PPM & Neutral \\
\hline
\end{tabular}

Table.3 Effect of mulching on growth parameters and physical character

\begin{tabular}{|r|l|c|c|c|c|c|c|}
\hline $\begin{array}{c}\text { S. } \\
\text { No }\end{array}$ & \multicolumn{1}{|c|}{ Treatments } & $\begin{array}{c}\text { Plant height } \\
(\mathrm{cm})\end{array}$ & $\begin{array}{c}50 \% \\
\text { Flowering }\end{array}$ & $\begin{array}{c}\text { Number of } \\
\text { primary } \\
\text { branch }\end{array}$ & $\begin{array}{c}\text { Number of } \\
\text { secondary branch }\end{array}$ & $\begin{array}{c}\text { Dry matter } \\
(\mathrm{g})\end{array}$ & $\begin{array}{c}\text { Leaf area } \\
\text { index }\end{array}$ \\
\hline $\mathbf{T}$ 1 & $\begin{array}{l}\text { Black Polytheen mulching + Drip } \\
\text { irrigation }\end{array}$ & 92.2 & 72.5 & 115.3 & 225.3 & 38.2 & 2.25 \\
\hline $\mathbf{T}_{2}$ & Unmulched + Surface Irrigation & 79.3 & 85.2 & 97.3 & 185.2 & 29.6 & 1.37 \\
\hline & $\mathbf{C V}$ & 3.55 & 4.80 & 4.15 & 3.21 & 12.49 & 13.21 \\
\hline & $\mathbf{C D}(\mathbf{0 . 0 5 \% )}$ & 5.59 & 7.65 & 6.48 & 8.83 & 7.98 & 0.89 \\
\hline
\end{tabular}


Table.4 Effect of mulching on fruit weight, yield and cost benefit ratio

\begin{tabular}{|c|c|c|c|c|c|c|}
\hline S.No. & Treatment & Fruit weight (g) & Yield (ton/ha) & Net Cost & Gross Profit & Net Return \\
\hline $\mathbf{T}_{\mathbf{1}}$ & $\begin{array}{c}\text { Black polythene } \\
\text { mulching + Drip } \\
\text { Irrigation }\end{array}$ & 84.3 & 33.2 & 15,637 & 44,377 & 28,740 \\
\hline $\mathbf{T}_{\mathbf{2}}$ & $\begin{array}{c}\text { Unmulched + } \\
\text { Surface Irrigation }\end{array}$ & 65.8 & 25.3 & 10,890 & 26,211 & 15,321 \\
\hline $\mathbf{C V}$ & 5.60 & 7.36 & & & \\
\hline & $\mathbf{C D}(\mathbf{0 . 0 5 \%})$ & 7.24 & 4.52 & & & \\
\hline
\end{tabular}

\section{References}

Agrawal, N., Panigrahi, H.K., Sharma, D. and Agrawal, R. 2010. Effect of different colour mulches on the growth and yield of tomato under Chhattisgarh region. Indian Journal of Horticulture, 67: 295-300. Agong.

S.G., Schittenhelm, S. and Friedt, W., 2001. Genotypic variation of Kenyan tomato (Lycopersicon esculentum Mill) germplasm. Journal of Food and Technology, 1: 13-17.

Abdalbagi, A.H., Salih, O.S., Abdu, E.A. and Ahmed, M.E. 2010. Effect of sowing date and plant density on growth and yield of tomato (Solanum lycopersicum Mill.). Research Journal of Agriculture and Biological Sciences, 6(5): 665-669.

Ashrafuzzaman, M., Abdul-hamid, M., Ismail, M.R. and Sahidullah, S.M., 2011. Effect of plastic mulch on growth and yield of chilli (Capsicum аппиит L.). Brazilian Archives of Biology and Technology, 54(2): 321330.

Bhella, H.S., 1988. Tomato response of trickle irrigation and black polyethylene mulch. Journal of the American Society for Horticultural Science, 113(4): 543-546.

Bhujbal, P.D., Tambe, T.B. and Ulemale, P.H., 2015. Effects of mulches on growth and yield of tomato (Lycopersicon esculentum Mill.). Bioinformation Letter, 12(2B): 464-466.

Choudhary, V.K., Bhambri, M.C., Pandey N. and Sharma, H.G., 2012. Effect of drip irrigation and mulches on physiological parameters, soil temperature, picking parameters and yield in capsicum (Capsicum annuum L.). Archives of Agronomy and Soil Science, 58(3): 277-292.

Singh, I.S., Awasthi, O.P., Dhandar, D.G. and Meena, S.S. 2005. Plastic and organic mulching in brinjal. In: International Conference on Plasticulture and Precision Farming held during 17- 21 November, New Delhi, p. 501.

Singh, A.K. and Kamal, S., 2012. Effect of black plastic mulch on soil temperature and tomato yield in mild hills of Garhwal Himalayas. Journal of Horticulture and Forestry, 4(4): 78-80.

Singh, B., Kumar, M. and Singh, G.C. 2005. Effects of different plastic mulches on growth and yield of winter tomato. Indian Journal of Horticulture, 62(2): 200-202.

Singh, R. 2005. Influence of mulching on growth and yield of Tomato (Lycopersicon esculentum Mill.) in north Indian plains. Vegetable Science, 32(1): 55-58.

Teasdale, J.R. and Mohler, C.L., 2000. The quantitative relationship between 
weed emergence and the physical properties of mulches. Weed Science, 48(3): 385-392.

Thakur, B.R., Singh, R.K. and Nelson, P. 1996. Quality attributes of processed tomato products: A review. Food Research International, 12: 375-401.

Thakur, P. S., Thakur, A. and Kanaujia, S.P., 2000. Reversal of water stress effects Mulching impact on the performance of Capsicum under water deficit. Indian Journal of Horticulture, 57(3): 250-254.

Uniyal, S.P. and Mishra, A.C., 2003. Response of potato to soil moisture and temperature as affected by different mulch materials. Journal of Indian Potato Association, 30(3-4): 53-56.

More, S.J., Bhanderi, D.R., Patil, S.J., Kadam, Y.R. and Patel, J.C. 2013. Effect of transplanting dates and mulching on fruit characters, yield and quality of tomato (Lycopersicon esculentum Mill.) cv. Gujarat Tomato-2. Crop Research, 46(1, 2\&3): 185-187.

Mukherjee A, Kundu, M. Sarkar, S, 2010. Role of irrigation and mulch on yield, evapotranspiration rate and water use pattern of tomato (Lycopersicon esculentum L.) Agriculture Water Management, 98(1):182-189.

\section{How to cite this article:}

Chanchila Kumari, Binit Kumar and Manish Kumar. 2018. Utilization of Polythene Mulching under Protected Cultivation of Tomato: A Method to Minimize Amount of Irrigation Under Semi Arid Ecosystem of Jharkhand, India. Int.J.Curr.Microbiol.App.Sci. 7(08): 4315-4320. doi: https://doi.org/10.20546/ijcmas.2018.708.452 